\title{
Effect of Zinc Fertilization on Physiological Parameters, Nutrient Uptake, Yield and Economics of Babycorn
}

\author{
Tamil Amutham $\mathbf{G}^{1 *}$, Karthikeyan $\mathbf{R}^{1}$, Thavaprakaash $\mathbf{N}^{1}$ and Bharathi $\mathbf{C}^{2}$ \\ ${ }^{1}$ Department of Agronomy, Tamil Nadu Agricultural University, Coimbatore- 641003. \\ ${ }^{2}$ Department of Soil Science and Agricultural Chemistry, Tamil Nadu Agricultural University, Coimbatore- 641003.
}

\begin{abstract}
A field experiment was conducted during late Kharif (September-November) of the year 2018 at Eastern Block Farm, Tamil Nadu Agricultural University, Coimbatore to find out the effect of agronomic bio-fortification with zinc on physiological parameters, nutrient uptake, yield and economics of babycorn under irrigated condition. The field experiment was laid in randomized complete block design with three replications. The treatments comprised of $\mathrm{T}_{1}$ : No zinc (control), $\mathrm{T}_{2}$ : Zinc Sulphate ( $\left.\mathrm{ZnSO}_{4}\right)$ at $25 \mathrm{kgha}^{-1}$ as soil application, $\mathrm{T}_{3}: \mathrm{ZnSO}_{4}$ at 37.5 kgha $^{-1}$ as soil application, $\mathrm{T}_{4}$ : Foliar spray of $\mathrm{ZnSO}_{4}$ at $0.5 \%$ on 20 and 40 DAS, $\mathrm{T}_{5}$ : Foliar spray of $\mathrm{ZnSO}_{4}$ at $1.0 \%$ on 20 and 40 DAS, $\mathrm{T}_{6}: \mathrm{ZnSO}_{4}$ at $25 \mathrm{kgha}^{-1}$ as soil application + foliar spray at $0.5 \%$ on 20 and $40 \mathrm{DAS}, \mathrm{T}_{7}: \mathrm{ZnSO}_{4}$ at $25 \mathrm{kgha}^{-1}$ as soil application + foliar spray at $1.0 \%$ on 20 and 40 DAS $\mathrm{T}_{8}: \mathrm{ZnSO}_{4}$ at $37.5 \mathrm{kgha}^{-1}$ as soil application + foliar spray at $0.5 \%$ on 20 and 40 DAS T: $: \mathrm{ZnSO}_{4}$ at $37.5 \mathrm{kgha}^{-1}$ as soil application + foliar spray at $1.0 \%$ on 20 and 40 DAS. Babycorn hybrid G-5414 was used to experiment with a plant spacing of $45 \mathrm{~cm} \times 25 \mathrm{~cm}$. The results showed that the combined application of zinc sulphate @ $37.5 \mathrm{kgha}^{-1}$ with $0.5 \%$ foliar spray at 20 and 40 DAS recorded significantly higher Crop Growth Rate (CGR) $(31.07,30.83) \mathrm{gcm}^{-2}$ day $^{-1}$, Relative Growth Rate (RGR) (110.25, 31.67) $\mathrm{mgg}^{-1}$ day $^{-1}$ and Net Assimilation Rate (NAR) $(9.65,4.54) \mathrm{mgcm}^{-2}$ day $^{-1}$ at 25-45 DAS and 45 DAS - harvest intervals respectively. NPK uptake was recorded higher in $\left(\mathrm{T}_{8}\right)$ and green cob yield was recorded higher in $\left(\mathrm{T}_{9}\right)$ at harvest stage. Green fodder yield and higher benefit cost ratio was obtained higher with soil application of zinc sulphate @ $37.5 \mathrm{kgha}^{-1}$ with $0.5 \%$ foliar spray at 20 and 40 DAS.
\end{abstract}

Keywords: Babycorn; G 5414; Crop growth rate and Total zinc uptake

\section{INTRODUCTION}

Maize is the third most important cereal crop, next to rice and wheat. The novelty of maize is cultivating it predominantly for vegetable purpose as "babycorn". Babycorn is typically a maize ear (Zea mays L.) produced from regular corn plants which are harvested earlier, particularly when the silks have the size of $1-3 \mathrm{~cm}$ (Thavaprakaash et al., 2005). Worldwide, Thailand is the leading producer and exporter of babycorn. India is emerging as the potential producer of babycorn due to high demand with less cost of production. The average productivity of babycorn in India is about 7.5-8.7 tonnes ha-1 (Mohinder et al., 2017).

In humans, $\mathrm{Zn}$ occupies an essential role in normal healthy growth and development to regulate the immune system, sensory functions, reproductive health and neurobehavioral development
(Hershfinkel et al., 2007). In Asia, about 2.50 billion people suffer from zinc deficiencies between the age group of 0 and 5 years (Caballero, 2002). Among the field crops, maize is a highly susceptible crop to zinc and it can be used for as an indicator plant of zinc deficiency. Bio-fortification works for the twin objective of increasing the concentration of the micronutrients in the grains and simultaneously improving the bioavailability of micronutrients in the grains to alleviate the micronutrient deficiency in human beings. Agronomic zinc bio-fortification in babycorn has a great scope in alleviating zinc related deficiencies by human consumption of $\mathrm{Zn}$ rich babycorn. Hence, the present study aimed to study the agronomic bio-fortification with zinc on yield and economics of babycorn.

\section{Material and methods}

A field experiment was conducted during late 
Kharif (September-November) of the year 2018 at Eastern Block Farm, Tamil Nadu Agricultural University, Coimbatore in sandy clay loam textured soil. The farm is located in the Western Agro Climatic Zone of Tamil Nadu at $11^{\circ} \mathrm{N}$ latitude, $77^{\circ} \mathrm{E}$ longitude and at an altitude of $426.7 \mathrm{~m}$ above the MSL. The soil of experimental field was slightly alkaline in nature (8.74), medium in organic carbon (0.53\%), low available nitrogen (202 $\left.\mathrm{kgha}^{-1}\right)$, medium in available phosphorus (20 $\left.\mathrm{kgha}^{-1}\right)$ and high in available potassium (757 kgha-1). The experiment was laid in Randomized Complete Block Design with nine treatments and three replications.The treatments comprised of $\mathrm{T}_{1}$ : No zinc (control), $\mathrm{T}_{2}: \mathrm{ZnSO}_{4}$ at $25 \mathrm{kgha}^{-1}$ as soil application, $\mathrm{T}_{3}: \mathrm{ZnSO}_{4}$ at $37.5 \mathrm{kgha}^{-1}$ as soil application, $\mathrm{T}_{4}$ : Foliar spray of $\mathrm{ZnSO}_{4}$ at $0.5 \%$ on 20 and 40 DAS, $\mathrm{T}_{5}$ : Foliar spray of $\mathrm{ZnSO}_{4}$ at $1.0 \%$ on 20 and 40 DAS, $\mathrm{T}_{6}: \mathrm{ZnSO}_{4}$ at $25 \mathrm{kgha}^{-1}$ as soil application + foliar spray at $0.5 \%$ on 20 and $40 \mathrm{DAS} \mathrm{T}_{7}: \mathrm{ZnSO}_{4}$ at $25 \mathrm{kgha}^{-1}$ as soil application + foliar spray at $1.0 \%$ on 20 and 40 DAS $\mathrm{T}_{8}: \mathrm{ZnSO}_{4}$ at $37.5 \mathrm{kgha}^{-1}$ as soil application + foliar spray at $0.5 \%$ on 20 and $40 \mathrm{DAS} \mathrm{T}_{9}: \mathrm{ZnSO}_{4}$ at 37.5 $\mathrm{kgha}^{-1}$ as soil application + foliar spray at $1.0 \%$ on 20 and 40 DAS.

During the cropping period, a total rainfall of $324.4 \mathrm{~mm}$ was received in 31 rainy days. All the treatments received the blanket recommended dosage of NPK (150:60:40 kgha-1), applied in the form of urea, single super phosphate and muriate of potash, respectively. $\mathrm{N}$ and $\mathrm{K}$ were applied in two equal splits i.e., as basal and top dressing on 25 days after sowing (DAS) while the entire dose of $P$ was applied as basal. The quantity of zinc sulphate @ $25 \mathrm{kgha}^{-1}$ and $37.5 \mathrm{kgha}^{-1}$ was applied as basal and foliar application of zinc sulphate @ 0.5\% and $1.0 \%$ given at 20 and 40 DAS as per the treatments. The plant samples collected at various growth stages (25 DAS, 45 DAS and at harvest) were shade dried followed by oven dried and ground into fine powder using Wiley mill and used for chemical analysis of total $\mathrm{N}, \mathrm{P}, \mathrm{K}$ and $\mathrm{Zn}$ as given below

The uptake of nutrients (NPK and Zn) was worked out using the following formula.

$\begin{aligned} & \text { Nutrient uptake } \\ & \left(\mathrm{kgha}^{-1}\right)\end{aligned}=\frac{\begin{array}{l}\text { Percentage of nutrient } x \text { Total } \\ \text { drymatter production }\left(\mathrm{kgha}^{-1}\right)\end{array}}{100}$

\section{Physiological parameters}

\section{Crop Growth Rate (CGR)}

Crop Growth Rate (CGR) is defined as the drymatter accumulation per unit area of land. CGR plays a vital role in influencing the productivity of crops. CGR was calculated using the formula of Williams (1946) and expressed in $\mathrm{gcm}^{-2} \mathrm{day}^{-1}$.

$$
\mathrm{CGR}=\frac{\mathrm{W}_{2}-\mathrm{W}_{1}}{\mathrm{P}\left(\mathrm{t}_{2}-\mathrm{t}_{1}\right)}
$$

Where,

$W_{1}$ and $W_{2}$ were the plant dry weight (g) recorded at time $t_{1}$ and $t_{2}$ in days respectively and

$$
\mathrm{P}=\text { spacing in } \mathrm{cm}^{2} \text {. }
$$

\section{Relative Growth Rate (RGR)}

Relative Growth Rate (RGR) is defined as the amount of growing substance per unit dry weight of plant per unit time. It is expressed as $\mathrm{mg} \mathrm{g}^{-1}$ day $^{-1}$. The RGR was calculated using the formula of Williams (1946).

$$
\mathrm{RGR}=\frac{\log _{\mathrm{e}} \mathrm{W}_{2}-\log _{\mathrm{e}} \mathrm{W}_{1}}{\mathrm{t}_{2}-\mathrm{t}_{1}}
$$

Where,

$W_{1}$ and $W_{2}$ were the plant dry weights $(g)$ recorded at time $t_{1}$ and $t_{2}$ in days respectively.

\section{Net Assimilation Rate (NAR)}

Net Assimilation Rate (NAR) is the rate of increase of leaf weight per unit area of leaf per unit time, expressed in $\mathrm{mgcm}^{-2} \mathrm{day}^{-1}$. The NAR was worked out by using the formula of Williams (1946).

$$
\text { NAR }=\frac{W_{2}-W_{1}}{t_{2}-t_{1}} \times \frac{\log _{e} L_{2}-\log _{e} L_{1}}{L_{2}-L_{1}}
$$

Where,

$W_{1}$ and $W_{2}$ were the plant dry weights $(g)$ recorded at time $t_{1}$ and $t_{2}$ in days, respectively and

$L_{1}$ and $L_{2}$ are the leaf area of the plant at time $t_{1}$ and $t_{2}$ respectively.

Based on the above formulas CGR, RGR and NAR were analysed and the total cost of cultivation, gross return, net return and benefit cost ratio were worked out for various zinc fertilization treatments. All the data were statistically analysed as per the procedure of Gomez and Gomez (2010).

\section{RESULTS AND DISCUSSION}

\section{Effect of zinc fertilization on physiological parameters of babycorn}

Crop Growth Rate is an important factor to decide LAl and dry matter accumulation per unit area of land. Crop Growth Rate (CGR) had a significant influence by zinc fertilization. Soil application of zinc sulphate @ $37.5 \mathrm{kgha}^{-1}$ with $0.5 \%$ foliar spray at 20 DAS and 40 DAS recorded the highest CGR at all stages. Increase in CGR might be due to nitrogen 
metabolism, which in turn influenced by zinc as both the nutrients are synergistic to each other. Hammad et al. (2011) also opined that zinc nutrition increased the nitrogen uptake that led to higher CGR.

Relative Growth Rate (RGR) is mainly used to assess the amount of growing substance per unit dry weight of plant per unit time. Soil application of zinc sulphate @ $37.5 \mathrm{kgha}^{-1}$ with $0.5 \%$ foliar spray at 20 DAS and 40 DAS recorded a higher RGR value which was comparable with other treatments of zinc fertilization over control. The results were in controversy with Sharma et al. (2017) reported increasing zinc concentration failed to show any variation on relative crop growth rate between 25 to 50 DAS and 50 to 70 DAS.

Perusal of the results from the experiment indicated that the zinc fertilization had a significant effect on NAR. Soil application of zinc sulphate @ $37.5 \mathrm{kgha}^{-1}$ with $0.5 \%$ foliar spray at 20 and 40 DAS recorded a higher NAR with an increment of $14.7 \%$ and $28.2 \%$ between 25 DAS and 45 DAS and between 45 DAS and harvest stages, respectively. The experimental results are in accordance with the findings of Palai et al. (2017) who reported that the higher rate of zinc applied as seed priming and foliar spray @ 2\% gave maximum NAR.

Table 1. Effect of zinc fertilization on CGR, RGR and NAR at different growth stages of babycorn

\begin{tabular}{|c|c|c|c|c|c|c|}
\hline \multirow{2}{*}{ Treatments } & \multicolumn{2}{|c|}{ CGR g cm cmay $^{-1}$} & \multicolumn{2}{|c|}{ RGR mg g-1 day ${ }^{-1}$} & \multicolumn{2}{|c|}{ NAR mg cm m $^{-2}$ day $^{-1}$} \\
\hline & 25-45 DAS & 45 DAS - H & 25-45 DAS & 45 DAS - H & 25-45 DAS & 45 DAS - H \\
\hline $\mathrm{T}_{1}:$ Control (No Zinc) & 23.4 & 20.7 & 105.9 & 29.4 & 8.4 & 3.5 \\
\hline $\begin{array}{l}\mathrm{T}_{2}: \mathrm{ZnSO}_{4} @ 25 \mathrm{kgha}^{-1} \text { as soil } \\
\text { application }\end{array}$ & 25.3 & 23.9 & 106.7 & 30.3 & 8.4 & 3.8 \\
\hline $\begin{array}{l}\mathrm{T}_{3}: \mathrm{ZnSO}_{4} @ 37.5 \mathrm{kgha}^{-1} \text { as soil } \\
\text { application }\end{array}$ & 26.5 & 25.1 & 108.1 & 30.5 & 8.5 & 3.8 \\
\hline $\begin{array}{l}\mathrm{T}_{4}: \text { Foliar spray of } \mathrm{ZnSO}_{4} @ 0.5 \% \text { on } \\
20 \text { and } 40 \text { DAS }\end{array}$ & 27.3 & 26.3 & 108.2 & 30.8 & 8.7 & 4.0 \\
\hline $\begin{array}{l}\mathrm{T}_{5}: \text { Foliar spray of } \mathrm{ZnSO}_{4} @ 1.0 \% \text { on } \\
20 \text { and } 40 \text { DAS }\end{array}$ & 27.1 & 25.7 & 108.2 & 30.5 & 8.7 & 3.9 \\
\hline$T_{6}: T_{2}+T_{4}$ & 28.1 & 27.4 & 108.4 & 31.1 & 8.7 & 4.0 \\
\hline$T_{7}: T_{2}+T_{5}$ & 28.7 & 28.2 & 108.5 & 31.3 & 9.1 & 4.2 \\
\hline$T_{8}: T_{3}+T_{4}$ & 31.1 & 30.8 & 110.3 & 31.7 & 9.7 & 4.5 \\
\hline$T_{9}: T_{3}+T_{5}$ & 29.7 & 29.3 & 109.2 & 31.4 & 9.3 & 4.4 \\
\hline SEd & 1.0 & 1.5 & 3.3 & 0.8 & 0.4 & 0.3 \\
\hline$C D(P=0.05)$ & 2.1 & 3.2 & NS & 1.7 & 0.8 & 0.5 \\
\hline
\end{tabular}

\section{Effect of zinc fertilization on nutrients uptake of babycorn}

Nutrient uptake is the function of nutrient concentration in plants and drymatter yield. Among the different levels of application of zinc sulphate tested, combined application of zinc sulphate of $37.5 \mathrm{kgha}^{-1}$ in soil with foliar spray of $0.5 \%$ on 20 DAS and 40 DAS had a profound influence on $\mathrm{N}$ uptake during different growth stages. The $\mathrm{N}$ uptake consistently increased with enhanced $\mathrm{Zn}$ doses. The uptake and accumulation of $\mathrm{N}$ in plants was enhanced by zinc fortification. This might be due to the synergistic effect of $\mathrm{Zn}$ on $\mathrm{N}$ and also due to better foraging capacity of roots led to better growth and development. The results of the study were in accordance with the findings of Shivay and Prasad (2014).

The P uptake had not been significantly influenced by zinc fertilization at all growth stages.

The K uptake was significantly influenced by zinc fertilization at all growth stages. Application of zinc sulphate @ $37.5 \mathrm{kgha}^{-1}$ with foliar spray of either $0.5 \%$ or $1.0 \%$ at 20 DAS and 40 DAS recorded higher $\mathrm{K}$ uptake during all growth stages. Higher availability of $\mathrm{K}$ was probably due to synergistic effect between $\mathrm{Zn}$ and $\mathrm{K}$. The results are in conformity with the findings of Meena et al. (2013) in maize crop.

Zinc is an important micro nutrient required for normal healthy growth and development of plant. Zinc fertilization had significantly influenced the zinc uptake in babycorn. Application of zinc sulphate in soil @ $37.5 \mathrm{kgha}^{-1}$ with foliar spray of either 0.5\% or $1.0 \%$ at 20 DAS and 40 DAS recorded higher $Z n$ uptake during all the growth stages. Application of zinc through soil and foliar application had enhanced the zinc concentration in the plants. This might be due to that higher micro nutrient concentration in plants was improved by micro nutrient concentration in the soil that facilitated greater absorption coupled with foliar spray which resulted in better translocation of the nutrient from source to sink. 
Table 2. Effect of zinc fertilization on plant N, P, K and Zn uptake at different stages of babycorn

\begin{tabular}{|c|c|c|c|c|c|c|c|c|c|c|c|c|}
\hline \multirow{2}{*}{ Treatments } & \multicolumn{3}{|c|}{$\begin{array}{c}\text { Total Nitrogen uptake } \\
\left(k^{\left(k^{\prime} a^{-1}\right)}\right.\end{array}$} & \multicolumn{3}{|c|}{$\begin{array}{l}\text { Total Phosphorus uptake } \\
\left(\mathrm{kgha}^{-1}\right)\end{array}$} & \multicolumn{3}{|c|}{$\begin{array}{c}\text { Total Potassium uptake } \\
\left(\mathrm{kgha}^{-1}\right)\end{array}$} & \multicolumn{3}{|c|}{$\begin{array}{l}\text { Total Zinc uptake } \\
\left(\mathrm{gha}^{-1}\right)\end{array}$} \\
\hline & 25 DAS & 45 DAS & Harvest & 25 DAS & 45 DAS & Harvest & 25 DAS & 45 DAS & Harvest & 25 DAS & 45 DAS & Harvest \\
\hline $\mathrm{T}_{1}$ & 17.8 & 95.7 & 124.1 & 0.9 & 10.3 & 12.5 & 6.6 & 66.3 & 95.1 & 35.4 & 209.5 & 286.8 \\
\hline $\mathrm{T}_{2}$ & 18.5 & 101.7 & 162.2 & 1.0 & 12.6 & 16.1 & 7.1 & 73.6 & 111.7 & 41.9 & 260.1 & 335.3 \\
\hline $\mathrm{T}_{3}$ & 20.2 & 117.5 & 167.6 & 1.1 & 12.5 & 16.0 & 7.3 & 86.6 & 111.5 & 42.7 & 234.9 & 385.8 \\
\hline $\mathrm{T}_{4}$ & 21.0 & 130.1 & 176.2 & 1.1 & 12.6 & 16.8 & 7.7 & 99.6 & 121.9 & 57.0 & 240.4 & 422.8 \\
\hline $\mathrm{T}_{5}$ & 21.7 & 129.2 & 180.4 & 1.1 & 12.9 & 16.5 & 7.8 & 94.2 & 129.6 & 54.9 & 320.5 & 439.0 \\
\hline $\mathrm{T}_{6}$ & 22.3 & 131.3 & 187.3 & 1.1 & 13.8 & 22.1 & 7.8 & 94.4 & 141.4 & 58.5 & 370.0 & 504.0 \\
\hline $\mathrm{T}_{7}$ & 23.2 & 137.9 & 192.9 & 1.3 & 14.3 & 25.3 & 8.8 & 107.8 & 151.0 & 58.7 & 384.6 & 507.1 \\
\hline $\mathrm{T}_{8}$ & 24.0 & 147.4 & 207.3 & 1.3 & 14.8 & 25.6 & 9.4 & 115.0 & 158.0 & 63.5 & 430.0 & 544.5 \\
\hline$T_{9}$ & 24.0 & 141.4 & 195.1 & 1.4 & 14.9 & 25.4 & 9.3 & 114.8 & 158.3 & 63.6 & 428.6 & 567.3 \\
\hline SEd & 1.3 & 8.1 & 11.3 & 0.1 & 1.1 & 1.3 & 0.5 & 6.2 & 7.2 & 3.0 & 10.2 & 32.0 \\
\hline$C D(P=0.05)$ & 2.7 & 17.2 & 24.0 & 0.1 & 2.3 & 2.7 & 1.0 & 13.1 & 15.3 & 6.4 & 21.7 & 67.8 \\
\hline
\end{tabular}

\section{Effect of zinc fertilization on yield of babycorn}

Zinc fertilization had a significant effect on green cob yield. Each successive level of zinc application correspondingly improved the yield of green cob up to the highest level under testing. Soil application of zinc sulphate at $25 \mathrm{kgha}^{-1}$ and $37.5 \mathrm{kgha}^{-1}$ and foliar spray @ 0.5\% and 1.0\% were statistically similar and increased the green cob yield to the tune of 19.5 percent, 21.5 per cent, 24 per cent and 24.6 per cent, respectively as per the successive increment in zinc fertilization over control. The increased yield might be due to the beneficial effect of $Z n$ in the plant system. Better utilization of zinc resulted in higher leaf area, photosynthetic efficiency, the total drymatter production and yield attributes that led to an increased green cob yield.

Table 3. Effect of zinc fertilization on yield of babycorn

\begin{tabular}{|c|c|c|}
\hline Treatments & $\begin{array}{l}\text { Green } \\
\text { cob yield } \\
\left(\mathrm{kgha}^{-1}\right)\end{array}$ & $\begin{array}{l}\text { Green fodder } \\
\text { yield }\left(\mathrm{kgha}^{-1}\right)\end{array}$ \\
\hline $\mathrm{T}_{1}:$ Control (No Zinc) & 14378 & 24136 \\
\hline $\begin{array}{l}\mathrm{T}_{2}: \mathrm{ZnSO}_{4} @ 25 \mathrm{kgha}^{-1} \text { as soil } \\
\text { application }\end{array}$ & 16115 & 25615 \\
\hline $\begin{array}{l}\mathrm{T}_{3}: \mathrm{ZnSO}_{4} @ 37.5 \mathrm{kgha}^{-1} \text { as } \\
\text { soil application }\end{array}$ & 16328 & 26121 \\
\hline $\begin{array}{l}\mathrm{T}_{4} \text { : Foliar spray of } \mathrm{ZnSO}_{4} @ 0.5 \\
\% \text { on } 20 \text { and } 40 \mathrm{DAS}\end{array}$ & 16425 & 26385 \\
\hline $\begin{array}{l}\mathrm{T}_{5}: \text { Foliar spray of } \mathrm{ZnSO}_{4} @ 1.0 \\
\% \text { on } 20 \text { and } 40 \mathrm{DAS}\end{array}$ & 16571 & 26695 \\
\hline $\mathrm{T}_{6}: \mathrm{T}_{2}$ and $\mathrm{T}_{4}$ & 17189 & 28160 \\
\hline $\mathrm{T}_{7}: \mathrm{T}_{2}$ and $\mathrm{T}_{5}$ & 17476 & 28842 \\
\hline $\mathrm{T}_{8}: \mathrm{T}_{3}$ and $\mathrm{T}_{4}$ & 17837 & 30492 \\
\hline$T_{9}: T_{3}$ and $T_{5}$ & 17916 & 29706 \\
\hline SEd & 787 & 1162 \\
\hline$C D(P=0.05)$ & 1669 & 2463 \\
\hline
\end{tabular}

Application of zinc sulphate in soil @ 37.5 kgha-1 $^{-1}$ with foliar spray of $0.5 \%$ on 20 and 40 DAS recorded the maximum green fodder yield (30492 kgha-1) with an increment of 26 per cent over control. The favourable effect of $\mathrm{Zn}$ application on green fodder yield was attributed to the overall growth and development under higher supply of zinc which enhanced the source to sink relationship and led to increase the green fodder yield.

\section{Effect of zinc fertilization on economics of babycorn}

The economic analysis of different treatments revealed large variations in cost of cultivation, gross return, net return and benefit cost ratio in babycorn.

Among the treatments, higher cultivation cost ₹ 78612 ha $^{-1}$ was incurred with soil application of zinc sulphate at $37.5 \mathrm{kgha}^{-1}$ with foliar spray of $1.0 \%$ on 20 DAS and 40 DAS $\left(T_{9}\right)$ than other treatments. The lowest cultivation cost of $₹ 75667$ ha $^{-1}$ was incurred with no zinc fertilization treatment (control).

The maximum value of gross return $₹ 417732$ ha-1 $^{-1}$ was obtained with soil application of zinc sulphate at $37.5 \mathrm{kgha}^{-1}$ and foliar spray of $1.0 \%$ on 20 DAS and 40 DAS $\left(T_{9}\right)$. The lowest gross return $₹ 338532$ ha $^{-1}$ was obtained in control $\left(T_{1}\right)$.

With regard to net return, soil application of zinc sulphate @ $37.5 \mathrm{kgha}^{-1}$ and foliar spray of $0.5 \%$ at 20 DAS and $40 \mathrm{DAS}\left(\mathrm{T}_{8}\right)$ recorded the highest net return of ₹ 339422 ha-1 $^{-1}$ followed by soil application of zinc sulphate at $37.5 \mathrm{kgha}^{-1}$ with foliar spray of $1.0 \%$ on 20 DAS and 40 DAS $\left(\mathrm{T}_{9}\right)$ recording ₹339120 ha-1. The lowest net return ₹260165 ha-1 was obtained in control (no zinc) treatment.

The benefit cost ratio was the highest (5.33) with soil application of zinc sulphate @ $37.5 \mathrm{kgha}^{-1}$ along with foliar spray of $0.5 \%$ at 20 DAS and 40 DAS $\left(\mathrm{T}_{8}\right)$ followed by zinc sulphate @ $37.5 \mathrm{kgha}^{-1}$

$107 \mid 10-12$ | 4 
with foliar spray of $1.0 \%$ at 20 DAS and 40 DAS $\left(T_{9}\right)$. The lowest benefit cost ratio (4.44) was obtained in control $\left(T_{1}\right)$. Economic efficiency and viability of crop production are dependent on higher crop productivity with lesser cost of cultivation which could result in better economic parameters like higher net return and $\mathrm{B}$ : $\mathrm{C}$ ratio. In general, during the course of experimentation, cost of cultivation was higher with the application of zinc sulphate with each successive increased level (either through soil application or as foliar spray) compared to no zinc application due to increased variable costs viz., cost of the input and application charges.

On consideration of the economics of babycorn as influenced by zinc fertilization it revealed that the application of zinc sulphate in soil @ $37.5 \mathrm{kgha}^{-1}$ with foliar spray @ 1.0\% at 20 and 40 DAS incurred higher cost of cultivation and attained higher gross return and benefit cost ratio of 5.31. Maximum net return and benefit cost ratio of 5.33 was recorded with the application of zinc sulphate in soil @ 37.5 kgha $^{-1}$ with foliar spray @ $0.5 \%$ at 20 and 40 DAS. This was attributed to the production of higher green cob and green fodder yields over other treatments. It is obvious because of the favourable effect of zinc application on production of higher babycorn and green fodder yield as well as remunerative returns in spite of higher cost of cultivation. Palai et al. (2018) found that the highest net return ( ₹165442 ha-1) was observed with soil application of Zn @ $6 \mathrm{kgha}^{-1}$ along with foliar spray @ 0.05\% Zn at 25 DAS with seed treatment @ $0.6 \% \mathrm{Zn}$. The B:C ratio was also highest (4.46) in soil application of Zn @ $6 \mathrm{kgha}^{-1}$ along with foliar spray @ 0.05\% Zn at 25 DAS.

Table 4. Economics of baby corn as influenced by zinc fertilization

\begin{tabular}{|c|c|c|c|c|}
\hline Treatments & $\begin{array}{l}\text { Total Cost of cultivation } \\
\qquad\left(₹_{\left.h a^{-1}\right)}\right.\end{array}$ & $\begin{array}{l}\text { Gross return } \\
\left(\text { ( }^{\text {ha }}{ }^{-1}\right)\end{array}$ & $\begin{array}{l}\text { Net return } \\
\left(\text { ( }_{\text {ha }}^{-1}\right)\end{array}$ & $\begin{array}{l}\text { B: C } \\
\text { Ratio }\end{array}$ \\
\hline $\mathrm{T}_{1}:$ Control (No Zinc) & 75667 & 335832 & 260165 & 4.44 \\
\hline $\mathrm{T}_{2}: \mathrm{ZnSO}_{4} @ 25 \mathrm{kgha}^{-1}$ as soil application & 77217 & 373530 & 296313 & 4.84 \\
\hline $\mathrm{T}_{3}: \mathrm{ZnSO}_{4} @ 37.5 \mathrm{kgha}^{-1}$ as soil application & 77992 & 378802 & 300810 & 4.86 \\
\hline $\mathrm{T}_{4}$ : Foliar spray of $\mathrm{ZnSO}_{4} @ 0.5 \%$ on 20 and 40 DAS & 75977 & 381270 & 305293 & 5.02 \\
\hline $\mathrm{T}_{5}:$ Foliar spray of $\mathrm{ZnSO}_{4} @ 1.0 \%$ on 20 and 40 DAS & 76287 & 384810 & 308523 & 5.04 \\
\hline$T_{6}: T_{2}+T_{4}$ & 77527 & 400100 & 322573 & 5.16 \\
\hline $\mathrm{T}_{7}: \mathrm{T}_{2}+\mathrm{T}_{5}$ & 77837 & 407204 & 329367 & 5.23 \\
\hline $\mathrm{T}_{8}: \mathrm{T}_{3}+\mathrm{T}_{4}$ & 78302 & 417724 & 339422 & 5.33 \\
\hline $\mathrm{T}_{9}: \mathrm{T}_{3}+\mathrm{T}_{5}$ & 78612 & 417732 & 339120 & 5.31 \\
\hline
\end{tabular}

( ${ }^{*}$ Data not statistically analysed)

\section{REFERENCES}

Caballero, B. 2002. Global patterns of child health: the role of nutrition.Ann Nutr., (Suppl. 1):3-7.

Gomez, K.A., and A.A. Gomez. 2010. Statistical procedures for agricultural research: John Wiley \& Sons.

Hammad, H.M., Ahmad, A. Khaliq,T. Farhad,W. and M. Mubeen. 2011. Optimizing rate of nitrogen application for higher yield and quality in maize under semiarid environment. Crop and Environment .,2 (1):38-41.

Hershfinkel, M., Silverman,W.F. and I. Sekler. 2007. The zinc sensing receptor, a linkbetween zinc and cell signaling. Mol Med., 13(7-8): 331-336.

Meena, S.K,Mundra,S.L.and P. Singh. 2013. Response of maize (Zea mays) to nitrogen and zinc fertilization. Indian J Agron.,58 (1):127-128.

Mohinder, P.S., Bakshi,M., Wadhwa, Harinder, P.S. and Makkar. 2017. Utilization of baby corn byproducts and waste as livestock feed. Broadening Horizons.,44.

Palai, J.B., Sarkar,N.C. and J. Jena. 2018. Effect of zinc on growth, yields, zinc use efficiency and economics in baby corn. Int. J. Pharmacogn Phytochem., 7 (2):1641-1645.

Palai, J.B., Sarkar, N.C. and J. Jena. 2017. Effect of zinc on growth, plant yield, NPK uptake and economics. Int. J. Bio-resource Environ. Agric. Sci.,8 (5):698702.

Sharma, R., Choudhary,R. and B.L. Jat. 2017. Effect of nitrogen and zinc fertilization on growth and productivity of maize. Int. J. Agric. Sci.,13 (2):161176.

Shivay, Y.S., and R. Prasad. 2014. Effect of source and methods of zinc application on corn productivity, nitrogen and zinc concentrations and uptake by high quality protein corn (Zea mays). Egypt. J. Exp. Biol. (Bot.) .,16 (1):72-78.

Thavaprakaash, N., Velayudham,K. and V.B. Muthukumar. 2005. Effect of crop geometry, intercropping systems and integrated nutrient management practices on productivity of baby corn (Zea mays L.) based intercropping systems. J. Agric. Biol. Sci.,1 (4):295-302.

Williams, R.F. 1946. The physiology of plant growth with special reference to the concept of net assimilation rate. Ann Bot.,10 (37):41-72. 